\title{
Evaluation of Adsorption Mechanism of Chromium(VI) Ion Using Ni-Al Type and Ni-Al-Zr Type Hydroxides
}

\author{
Fumihiko Ogata ${ }^{1}{ }^{\mathbb{D}}$, Noriaki Nagai ${ }^{1}$, Ayako Tabuchi ${ }^{1}$, Megumu Toda ${ }^{2}$, Masashi Otani ${ }^{2}$, \\ Chalermpong Saenjum ${ }^{3,4}$ (D) Takehiro Nakamura ${ }^{1}$ and Naohito Kawasaki ${ }^{1,5, *(D)}$ \\ 1 Faculty of Pharmacy, Kindai University, 3-4-1 Kowakae, Higashi-Osaka, Osaka 577-8502, Japan; \\ ogata@phar.kindai.ac.jp (F.O.); nagai_n@phar.kindai.ac.jp (N.N.); 1711710039w@kindai.ac.jp (A.T.); \\ nakamura@phar.kindai.ac.jp (T.N.) \\ 2 Kansai Catalyst Co. Ltd., 1-3-13, Kashiwagi-cho, Sakai-ku, Sakai, Osaka 590-0837, Japan; \\ megumu.toda@kansyoku.co.jp (M.T.); masashi.ootani@kansyoku.co.jp (M.O.) \\ 3 Faculty of Pharmacy, Chiang Mai University, Suthep Road, Muang District, Chiang Mai 50200, Thailand; \\ chalermpong.saenjum@gmail.com \\ 4 Cluster of Excellence on Biodiversity-Based Economics and Society (B.BES-CMU), Chiang Mai University, \\ Suthep Road, Muang District, Chiang Mai 50200, Thailand \\ 5 Antiaging Center, Kindai University, 3-4-1 Kowakae, Higashi-Osaka, Osaka 577-8502, Japan \\ * Correspondence: kawasaki@phar.kindai.ac.jp; Tel.: +81-6-4307-4012
}

check for updates

Citation: Ogata, F.; Nagai, N.; Tabuchi, A.; Toda, M.; Otani, M.; Saenjum, C.; Nakamura, T.; Kawasaki, N. Evaluation of Adsorption Mechanism of Chromium(VI) Ion Using Ni-Al Type and Ni-Al-Zr Type Hydroxides. Water 2021, 13, 551. https://doi.org/10.3390/w13040551

Academic Editors: Cristina Palet and Julio Bastos-Arrieta

Received: 22 January 2021

Accepted: 18 February 2021

Published: 21 February 2021

Publisher's Note: MDPI stays neutral with regard to jurisdictional claims in published maps and institutional affiliations.

Copyright: (c) 2021 by the authors. Licensee MDPI, Basel, Switzerland. This article is an open access article distributed under the terms and conditions of the Creative Commons Attribution (CC BY) license (https:/ / creativecommons.org/licenses/by/ $4.0 /)$.

\begin{abstract}
To evaluate the feasibility of nickel-aluminum (the $\mathrm{Ni}^{2+}: \mathrm{Al}^{3+}$ molar ratios of 1.0:1.0 and 1.0:2.0 are denoted as NA11 and NA12, respectively) and nickel-aluminum-zirconium type (the $\mathrm{Ni}^{2+}: \mathrm{Al}^{3+}: \mathrm{Zr}^{4+}$ molar ratios of 0.9:1.0:0.09 and 0.9:2.0:0.09 are denoted as NAZ1 and NAZ2, respectively) hydroxides for $\mathrm{Cr}(\mathrm{VI})$ removal from aqueous media, the adsorption capability and adsorption mechanism of $\mathrm{Cr}(\mathrm{VI})$ using the above-mentioned adsorbents were investigated in this study. The quantity of $\mathrm{Cr}$ (VI) adsorbed onto NA11, NA12, NAZ1, and NAZ2 was 25.5, 25.6, 24.1, and $24.6 \mathrm{mg} \mathrm{g}^{-1}$, respectively. However, the quantity of aluminum (base metal) released from NA11 (approximately $0.14 \mathrm{mg} \mathrm{g}^{-1}$ ) was higher than that from NAZ1 (approximately $1.0 \mu \mathrm{g} \mathrm{g}^{-1}$ ), indicating that NAZ1 was more suitable for $\mathrm{Cr}(\mathrm{VI})$ removal than NA11. In addition, the effects of $\mathrm{pH}$, contact time, and temperature on the adsorption of $\mathrm{Cr}(\mathrm{VI})$ were evaluated. Moreover, to elucidate the adsorption mechanism of $\mathrm{Cr}(\mathrm{VI})$ using NA11 and NAZ1, the elemental distribution, X-ray photoelectron spectrometry spectra, and ion exchange capability were also determined. $\mathrm{Cr}(\mathrm{VI})$ adsorbed onto the NAZ1 surface was easily desorbed using a sodium hydroxide solution under our experimental conditions. The information regarding this study can be useful for removing $\mathrm{Cr}(\mathrm{VI})$ from aqueous media.
\end{abstract}

Keywords: nickel-aluminum complex hydroxide; nickel-aluminum-zirconium complex hydroxide; chromium(VI); adsorption

\section{Introduction}

In 2015, the United Nations announced the 2030 agenda for sustainable development. Among the 17 Sustainable Development Goals (SGDs), Goal No. 6 (clean water and sanitation) and Goal No. 14 (life below water), which are directly and strongly related to the water environment, focused on resolving global aquatic environmental problems. Exposure to high level of water contamination by heavy metals is considered as a serious variety of adverse health outcomes [1]. As one of the most important contaminants, two main oxidation states including $\mathrm{Cr}(\mathrm{VI})$ and $\mathrm{Cr}(\mathrm{III})$ is present in the environment. Importantly, $\mathrm{Cr}(\mathrm{VI})$ compounds are widely used in various industrial processes. On the other hand, $\mathrm{Cr}(\mathrm{III})$ is used as a nutritional supplement [2]. $\mathrm{Cr}(\mathrm{VI})$ is usually considered more toxic and carcinogenic than $\mathrm{Cr}$ (III) [3,4]. Therefore, $\mathrm{Cr}$ (VI) compounds were classified as a group 1 carcinogenic to humans by the International Agency for Research on Cancer (IARC). In addition, the World Health Organization (WHO) and U.S. Environmental Protection Agency (USEPA) has established the maximum permissible $\mathrm{Cr}(\mathrm{VI})$ content for industrial 
wastewater, surface water, and drinking water in the values of $0.25,0.10$, and $0.05 \mathrm{mg} \mathrm{L}^{-1}$, respectively $[5,6]$. Conversely, chromium is stockpiled in Japan because it is a relatively rare metal with several applications. Japan is one of the main consumers of rare metals worldwide. However, the recycling technology of rare metals, including chromium, has not yet been developed. Therefore, the development of removal and/or recycling techniques for $\mathrm{Cr}(\mathrm{VI})$ from aqueous media is very important for establishing a sustainable society $[7,8]$.

Numerous techniques have been studied and applied to evaluate the $\mathrm{Cr}(\mathrm{VI})$ removal including membrane filtration, chemical precipitation, solvent extraction, adsorption, electrochemical reduction and oxidation, and photoreduction [9-12]. Adsorption is one of the best choice and most cost-effective technique of heavy metals removal such as $\mathrm{Cr}(\mathrm{VI})$, and the adsorption process indicates that adsorbents bind heavy metals by chemical binding, ion exchange, and physical attractive forces [1].

Currently, the physicochemical properties and feasibility of metal complex hydroxides have received more attention, and their application has been evaluated for the capability on heavy metals removal from aqueous media [13]. Various studies have reported previously for the capability of $\mathrm{Mg}$-Al- $\mathrm{CO}_{3}$-hydrotalcite [14,15], hydrotalcite-hydroxyapatite material doped with carbon nanotubes [16], Mg-Al hydrotalcite kaolin clay [17], hydrotalcite/carbon [18], sulfide assembled hydrotalcite compounds [19], calcined nano-Mg/ $\mathrm{Al}$ hydrotalcite [20], and metal oxide as dual-functional adsorbents [1] on $\mathrm{Cr}(\mathrm{VI})$ removal from aqueous media. In addition, our previous studies reported that Fe-Mg-type hydrotalcite and nickel-aluminum complex hydroxide showed excellent adsorption capability for $\mathrm{Cr}(\mathrm{VI})$ from aqueous media $[8,21]$. However, there are few reports on the adsorption/removal of heavy metals using ternary metal complex hydroxides from aqueous media. In addition, multi-complex metal hydroxides are useful adsorbents for removing heavy metals from aqueous media $[8,21]$. Multi-complex metal hydroxides exhibit quite different physicochemical properties compared to their single or double metal hydroxides.

Additionally, our previous studies reported that nickel-aluminum complex hydroxide and/or nickel-aluminum-zirconium complex hydroxide are useful for the removal of oxyanions, such as arsenic and phosphate ions, from aqueous media [22,23]. The incorporation of zirconium $\left(\mathrm{Zr}^{4+}\right)$ into a metal complex hydroxide induces an increase in the charge in the metal layer and strongly affects its physicochemical properties. These changes affect to the capability on adsorption and removal of heavy metals from aqueous media. We have already evaluated the $\mathrm{Cr}(\mathrm{VI})$ adsorption capability using nickel-aluminum complex hydroxide [21]. Additionally, $\mathrm{Cr}$ (VI) (oxyanion form) is ubiquitously present in the water environment. Therefore, the incorporation of zirconium in the nickel-aluminum complex hydroxide might be useful adsorbent for removal of $\mathrm{Cr}(\mathrm{VI})$ from aqueous media or might show the superior adsorption capability of $\mathrm{Cr}(\mathrm{VI})$. However, no information is available regarding $\mathrm{Cr}(\mathrm{VI})$ adsorption using the incorporation of zirconium in the nickel-aluminum complex hydroxide.

Therefore, this study mainly focused on $\mathrm{Cr}(\mathrm{VI})$ adsorption using the incorporation of zirconium in the nickel-aluminum complex hydroxide. Additionally, various parameters including the effects of initial concentration, temperature, $\mathrm{pH}$, and contact time on adsorption were also evaluated here.

\section{Materials and Methods}

\subsection{Materials and Chemicals}

Standard solutions of $\mathrm{Cr}(\mathrm{VI})\left(\mathrm{K}_{2} \mathrm{Cr}_{2} \mathrm{O}_{7}\right.$ in $\left.0.1 \mathrm{~mol} \mathrm{~L}^{-1} \mathrm{HNO}_{3}\right)$ was purchased from FUJIFILM Wako Pure Chemical Co., Osaka, Japan. Different molar ratios of nickel-aluminum complex hydroxides and nickel-aluminum-zirconium complex hydroxide were prepared in the molar ratios of $\mathrm{Ni}^{2+}$ to $\mathrm{Al}^{3+}$ of 1.0, and 0.5 , referred as NA11 and NA12, respectively. Additionally, the molar ratios of 0.9:1.0:0.09 and 0.9:2.0:0.09 $\mathrm{of} \mathrm{Ni}^{2+}: \mathrm{Al}^{3+}: \mathrm{Zr}^{4+}$ were denoted as NAZ1 and NAZ2, respectively. The synthesis method and physicochemical characteristics were reported in our previous studies [22]. Briefly, the materials were synthesized by the following method. $\mathrm{NiSO}_{4} \bullet 6 \mathrm{H}_{2} \mathrm{O}, \mathrm{Al}_{2}\left(\mathrm{SO}_{4}\right)_{3} \bullet 18 \mathrm{H}_{2} \mathrm{O}$, and $\mathrm{Zr}\left(\mathrm{SO}_{4}\right)_{2} \bullet 4 \mathrm{H}_{2} \mathrm{O}$ were mixed 
and then the reaction solution was heated. After that, the reaction solution was added to the distilled water at $\mathrm{pH} 9.0$ for $800 \mathrm{rpm}$ at $25^{\circ} \mathrm{C}$. After mixing for $2 \mathrm{~h}$, the suspension was filtered, washed, and dried at $110{ }^{\circ} \mathrm{C}$ for $12 \mathrm{~h}$. The adsorbent morphology and crystal structure were measured using SU1510 (Hitachi Ltd., Tokyo, Japan) and Mini Flex II (Rigaku, Tokyo, Japan), respectively. NOVA4200e instrument (Yuasa Ionics, Osaka, Japan) was used to measure the specific surface area. Amount of surface hydroxyl groups and $\mathrm{pH}_{\mathrm{pzc}}$ of the adsorbents were measured by the fluoride ion adsorption method [24] and the method reported by Faria et al. [25], respectively.

To elucidate the adsorption mechanism of $\mathrm{Cr}(\mathrm{VI})$, elemental analysis and electron spectroscopy were analyzed using JXA-8530F (JEOL, Tokyo, Japan) and AXIS-NOVA instruments (Shimadzu Co., Ltd., Kyoto, Japan), respectively. Finally, the amount of sulfate ions released from the adsorbent in the adsorption experiment was also measured using a DIONEX ICS-900 (Thermo Fisher Scientific Inc., Tokyo, Japan). The measurement conditions were already reported in our previous study [23]. Finally, the amount of base metal released from NA11 and NAZ1 was measured. NA11 or NAZ1 (0.05 g) was added to the distilled water $(50 \mathrm{~mL}, \mathrm{pH} 7.0)$. The suspension was shaken at $100 \mathrm{rpm}$ and $25{ }^{\circ} \mathrm{C}$ for $24 \mathrm{~h}$. The suspension was filtered through a $0.45 \mu \mathrm{m}$ membrane filter. The concentration of aluminum released from NA11 and NAZ1 were measured using an iCAP-7600 Duo instrument (Thermo Fisher Scientific Inc., Tokyo, Japan).

\subsection{Quantity of Cr(VI) Adsorbed}

Each adsorbent $(0.05 \mathrm{~g})$ and the $\mathrm{Cr}(\mathrm{VI})$ solution at $50 \mathrm{mg} \mathrm{L}^{-1}(50 \mathrm{~mL}, \mathrm{pH} 7.0)$ were mixed and then shaken at $100 \mathrm{rpm}$ and $25{ }^{\circ} \mathrm{C}$ for $24 \mathrm{~h}$. $\mathrm{Cr}(\mathrm{VI})$ concentrations of the obtained solutions after filtrated through a $0.45 \mu \mathrm{m}$ membrane filter were measured using an iCAP-7600 Duo instrument (Thermo Fisher Scientific Inc., Tokyo, Japan). The adsorption capability on $\mathrm{Cr}(\mathrm{VI})$ of each tested adsorbent was calculated by the difference between $\mathrm{Cr}(\mathrm{VI})$ concentration before and after adsorption. All data are presented as mean \pm standard error from triplicate experiments.

\subsection{Effect of $\mathrm{pH}$, Contact Time, and Temperature on the Removal of $\mathrm{Cr}(\mathrm{VI})$}

Initially, to investigate the effect of $\mathrm{pH}, 0.05 \mathrm{~g}$ of each tested adsorbent (NA11 and NAZ1), and different $\mathrm{pH}$ conditions of $50 \mathrm{~mL} \mathrm{Cr}(\mathrm{VI})$ solution in the concentration of $50 \mathrm{mg} \mathrm{L}^{-1}$ were mixed. The solution $\mathrm{pH}$ was adjusted between $3,5,7,9$, and 11 , using either nitric acid or sodium hydroxide solutions (FUJIFILM Wako Pure Chemical Co., Osaka, Japan). The suspension was shaken at $100 \mathrm{rpm}$ and $25^{\circ} \mathrm{C}$ for $24 \mathrm{~h}$. The suspension was filtered through a $0.45 \mu \mathrm{m}$ membrane filter. Second, to elucidate the contact time effect, $0.05 \mathrm{~g}$ of same adsorbents and the $50 \mathrm{~mL} \mathrm{Cr}(\mathrm{VI})$ solution at $50 \mathrm{mg} \mathrm{L}^{-1}$ were mixed, and then shaken at $100 \mathrm{rpm}$ and $25^{\circ} \mathrm{C}$ for $30 \mathrm{~s}, 1,5,10$, and $30 \mathrm{~min}$, and 1, 3, 6, 9, 15, 18, 21, 24, 30,42 , and $48 \mathrm{~h}$. Third, to elucidate the effect of temperature, $0.05 \mathrm{~g}$ of same adsorbents and the $\mathrm{Cr}(\mathrm{VI})$ solution at different concentrations $\left(10,20,30,40\right.$, and $\left.50 \mathrm{mg} \mathrm{L}^{-1}\right)$ were mixed, and then shaken at $100 \mathrm{rpm}$ and 5,25 , and $45^{\circ} \mathrm{C}$ for $24 \mathrm{~h}$. The quantity of $\mathrm{Cr}(\mathrm{VI})$ adsorbed was also calculated using the above-mentioned method. The student's $t$-test was used for a comparative analysis of two groups. A minimum $p$-value of $0.05(p<0.05)$ was chosen as the significant level. All data are presented as mean \pm standard error from triplicate experiments.

\subsection{Recovery of Cr(VI) From NAZ1 using Desorption Solutions}

To investigate the recovery of $\mathrm{Cr}(\mathrm{VI})$ adsorbed onto the NAZ1 surface, the adsorption/desorption performance of NAZ1 was evaluated in this section. First, NAZ1 (0.1 g) and the $\mathrm{Cr}(\mathrm{VI})$ solution at $100 \mathrm{mg} \mathrm{g}^{-1}(50 \mathrm{~mL})$ were mixed, and then the suspension was shaken at $100 \mathrm{rpm}$ and $25^{\circ} \mathrm{C}$ for $24 \mathrm{~h}$. Quantity of $\mathrm{Cr}(\mathrm{VI})$ adsorbed was also calculated as described the above. Second, NAZ1 was collected after adsorption, and then dried at $25{ }^{\circ} \mathrm{C}$ for $24 \mathrm{~h}$. Collected NAZ1 was added to the sodium hydroxide solution at 1, 10, and $100 \mathrm{mmol} / \mathrm{L}(50 \mathrm{~mL})$. The suspension was shaken at $100 \mathrm{rpm}$ and $25^{\circ} \mathrm{C}$ for $24 \mathrm{~h} . \mathrm{Cr}(\mathrm{VI})$ 
concentrations of the obtained solutions after filtrated through a $0.45 \mu \mathrm{m}$ membrane filter were measured using an iCAP-7600 Duo instrument. The quantity of Cr(VI) desorbed was calculated from the difference between the concentration of $\mathrm{Cr}(\mathrm{VI})$ before and after adsorption. All data are presented as mean \pm standard error from triplicate experiments.

\section{Results and Discussion}

\subsection{Physicochemical Properties}

First, NA11 and NA12 were selected for Cr(VI) removal from aqueous media. Because our previous study elucidated the optimal molar ratios condition of nickel and aluminum in the metal complex hydroxide for removal of $\mathrm{Cr}(\mathrm{VI})$ [21]. Additionally, previous studies showed that the incorporation of $\mathrm{Zr}^{4+}$ into a Ni-Al type hydroxide significantly improved the adsorption capability of oxyanions such as arsenic ions [22] and phosphate ions [23]. Therefore, the compositions of NA11, NA12, NAZ1, and NAZ2 were selected in this study. The physicochemical characteristics of NA11, NA12, NAZ1, and NAZ2 used in this study have already been reported in our previous studies [22]. Therefore, we briefly describe these properties. The prepared adsorbents were not perfectly spherical in shape under our experimental conditions. Additionally, no significant differences between each adsorbent were observed in this study. NA11 and NA12 have an amorphous nature [23]. The XRD patterns of NAZ1 and NAZ2 showed similar trends to those of NA11 and NA12. In addition, the XRD patterns of NAZ1 and NAZ2 showed that the incorporation of zirconium in the NA series could be successful, and then the distances between metals and between the octahedral layers changed in this study [22,26,27]. The specific surface areas of NA11, NA12, NAZ1, and NAZ2 were 22.8, 26.4, 51.9, and $27.8 \mathrm{~m}^{2} \mathrm{~g}^{-1}$, respectively. Additionally, the amount of surface hydroxyl groups was $1.92,1.62,1.08$, and $1.51 \mathrm{mmol} \mathrm{g}^{-1}$, respectively. Therefore, the incorporation of $\mathrm{Zr}^{4+}$ into a Ni-Al type hydroxide affects the increasing specifics surface area and the decreasing amount of surface hydroxyl groups under our experiment conditions. The $\mathrm{pH}_{\mathrm{pzc}}$ value of each adsorbent was between 6.2 and 6.4 under our experimental conditions.

\subsection{Quantity of $\mathrm{Cr}$ (VI) Adsorbed}

The quantity of $\mathrm{Cr}(\mathrm{VI})$ adsorbed onto NA11, NA12, NAZ1, and NAZ2 was $25.5 \pm 0.25 \mathrm{mg} \mathrm{g}^{-1}\left(1.1 \pm 0.011 \mathrm{mg} \mathrm{m}^{-2}\right), 25.6 \pm 0.12 \mathrm{mg} \mathrm{g}^{-1}\left(0.97 \pm 0.005 \mathrm{mg} \mathrm{m}^{-2}\right)$, $24.1 \pm 0.45 \mathrm{mg} \mathrm{g}^{-1}\left(0.46 \pm 0.001 \mathrm{mg} \mathrm{m}^{-2}\right)$, and $24.6 \pm 0.13 \mathrm{mg} \mathrm{g}^{-1}\left(0.88 \pm 0.005 \mathrm{mg} \mathrm{m}^{-2}\right)$, respectively. No significant difference was observed in $\mathrm{Cr}(\mathrm{VI})$ removal using the NA and NAZ series under our experimental conditions. The adsorption capability of $\mathrm{Cr}(\mathrm{VI})$ from aqueous media was not improved by incorporating zirconium in the nickel-aluminum complex hydroxide. In addition, the relationship between the quantity of $\mathrm{Cr}(\mathrm{VI})$ adsorbed and the physicochemical characteristics was evaluated. The correlation coefficient between the quantity of $\mathrm{Cr}(\mathrm{VI})$ adsorbed, and the surface hydroxyl groups was 0.890 , which indicates that this parameter was related to the adsorption of $\mathrm{Cr}(\mathrm{VI})$ using the NA and NAZ series.

The base metal released from the adsorbent is one of the most important issues in adsorption treatment. This phenomenon directly and strongly affects the adsorption capability of $\mathrm{Cr}(\mathrm{VI})$ using an adsorbent. Therefore, we evaluated the quantity of base metal released from NA11 and NAZ1 in a preliminary experiment. As a result, the quantity of aluminum released from NA11 (approximately $0.14 \mathrm{mg} \mathrm{g}^{-1}$ ) was greater than that from NAZ1 (approximately $1.0 \mu \mathrm{g} \mathrm{g}^{-1}$ ), which suggests that NAZ1 was more suitable for $\mathrm{Cr}(\mathrm{VI})$ removal than NA11. The incorporation of $\mathrm{Zr}^{4+}$ into NA11 increases the positive charge, and then more occupies the octahedral holes in a close-packed configuration of hydroxide ions. This phenomenon indicates that NAZ1 is more suitable compared to NA11 in this study. This result is very important for the application of NAZ1 in the field. Therefore, NAZ1 was used in the following adsorption experiment, and NA11 was also selected for comparison in this study.

Table 1 shows the comparison of the $\mathrm{Cr}(\mathrm{VI})$ adsorption capacities of NA11 and NAZ1 with those of other reported adsorbents. The adsorption capability of $\mathrm{Cr}$ (VI) using NA11 
and NAZ1 exhibited a similar trend to that of other reported adsorbents (except for calcined nano-Mg/Al hydrotalcite, and NiAl-LDH). Therefore, NAZ1 can be applied for the removal of $\mathrm{Cr}(\mathrm{VI})$ from aqueous media.

Table 1. Comparison of Cr(VI) adsorption capacity of NA11 and NAZ1 with other reported adsorbents.

\begin{tabular}{|c|c|c|c|c|c|c|c|}
\hline Adsorbents & $\begin{array}{l}\text { Adsorption } \\
\text { Capability } \\
\text { (mg/g) }\end{array}$ & $\mathrm{pH}$ & $\begin{array}{l}\text { Temp. } \\
\left({ }^{\circ} \mathrm{C}\right)\end{array}$ & $\begin{array}{c}\text { Initial } \\
\text { Concentration } \\
(\mathrm{mg} / \mathrm{L})\end{array}$ & $\begin{array}{l}\text { Contact } \\
\text { Time } \\
\text { (h) }\end{array}$ & $\begin{array}{l}\text { Adsorbent } \\
\text { (g/L) }\end{array}$ & Ref. \\
\hline $\begin{array}{c}\text { Calcined } \mathrm{Mg}-\mathrm{Al}-\mathrm{CO}_{3} \\
\text { hydrotalcite }\end{array}$ & $\begin{array}{l}\text { Approximately } \\
24\end{array}$ & 6.0 & 30 & 10 & 4 & 0.2 & [15] \\
\hline $\begin{array}{c}\text { Calcined nano-Mg/Al } \\
\text { hydrotalcite }\end{array}$ & 52.4 & 3.0 & 22 & 110 & 2 & 1 & [20] \\
\hline MgAl-LDH & 30.28 & $6-7$ & 25 & $30-55$ & 24 & 0.2 & [28] \\
\hline NiAl-LDH & 57.50 & $6-7$ & 25 & $30-55$ & 24 & 0.2 & [28] \\
\hline Ni-Fe-LDH & 26.78 & - & - & $4-20$ & $4-5$ & 0.2 & [29] \\
\hline Mg-Al-Cl LDH & 20.10 & 4.0 & 15 & 40 & 2 & 2 & [30] \\
\hline $\begin{array}{l}\mathrm{Mg}-\mathrm{Al}-\mathrm{CO}_{3} \\
\text { hydrotalcite }\end{array}$ & 17.00 & 6 & 30 & 10 & 24 & 1 & {$[31]$} \\
\hline NA11 & 25.5 & 7 & 25 & 100 & 24 & 1 & This study \\
\hline NAZ1 & 24.1 & 7 & 25 & 100 & 24 & 1 & This study \\
\hline
\end{tabular}

\subsection{Effect of $\mathrm{pH}$, Contact Time, and Temperature on the Removal of $\mathrm{Cr}(\mathrm{VI})$}

Solution $\mathrm{pH}$ is one of the most important parameters that directly and strongly affects the adsorption capability of $\mathrm{Cr}(\mathrm{VI})$ from aqueous media. Figure 1 exhibited the effect of $\mathrm{pH}$ on $\mathrm{Cr}(\mathrm{VI})$ adsorption using NA11 and NAZ1. In this experiment, the optimal $\mathrm{pH}$ condition for $\mathrm{Cr}(\mathrm{VI})$ removal using NA11 and NAZ1 was approximately between 7.0 and 9.0. Similar trends were reported by previous studies using $\mathrm{Mg}-\mathrm{Al}-\mathrm{Cl} \mathrm{LDH}$ and $\mathrm{Mg}-\mathrm{Al} \mathrm{LDH}[30,32]$. $\mathrm{Cr}(\mathrm{VI})$ oxyanion species in an aqueous solution depend on the solution $\mathrm{pH}$ and chromium concentration. The $\mathrm{Cr}(\mathrm{VI})$ oxyanion species in solution are chromate $\left(\mathrm{CrO}_{4}{ }^{2-}\right)$, dichromate $\left(\mathrm{Cr}_{2} \mathrm{O}_{7}{ }^{2-}\right)$, and hydrogen chromate $\left(\mathrm{HCrO}_{4}{ }^{-}\right)$[33]. The surfaces of NA11 and NAZ1 are protonated in acidic condition and therefore acquire positive charges. However, under strongly acidic condition ( $\mathrm{pH} 3.0)$, low $\mathrm{Cr}(\mathrm{VI})$ adsorption was observed. These phenomena can be explained by the dissolution of the adsorbent at low $\mathrm{pH}$ solution. Similar trends were reported by previous studies [17,32]. On the other hand, only chromate is stable in solution, and there are many hydroxide ions above a $\mathrm{pH}$ of 6.8. Therefore, competitive adsorption between hydroxide ions and chromate ions onto NA11 and NAZ1 occurred easily $[20,33,34]$. The removal efficiency of $\mathrm{Cr}(\mathrm{VI})$ using NA11 and NAZ1 decreased $\mathrm{pH}$ from 9.0 to 11. Considering the adsorption capability of $\mathrm{Cr}(\mathrm{VI})$ using NA11 and NAZ1, an initial $\mathrm{pH}$ of 7.0 was selected in the following experiments in this study.

Figure 2 demonstrated the contact time effect on $\mathrm{Cr}(\mathrm{VI})$ adsorption using NA11 and NAZ1 with adsorption kinetics. The data showed that the rapidly adsorption occurred during the initial $10 \mathrm{~min}$, and then it gradually became slower over time, reaching equilibrium in approximately $20 \mathrm{~h}$. Previous studies reported the adsorption capability of metal complex hydroxide on heavy metals was a very rapid process [29,32]. It takes within $2 \mathrm{~h}$ for $\mathrm{Cr}(\mathrm{VI})$ solution with an initial concentration of from 5 to $200 \mathrm{mg} \mathrm{g}^{-1}$ to reach equilibrium. However, the quantity of $\mathrm{Cr}(\mathrm{VI})$ adsorbed using NA11 and NAZ1 was slightly higher compared to the reported adsorbent. Additionally, amount adsorbent (adsorbents reported in previous studies) was more needed for $\mathrm{Cr}(\mathrm{VI})$ removal from aqueous media. Therefore, NA11 and NAZ1 were useful for removal of $\mathrm{Cr}(\mathrm{VI})$ from aqueous media. The process of $\mathrm{Cr}(\mathrm{VI})$ adsorption from aqueous media using an adsorbent can be elucidated by kinetic models, such as the pseudo-first-order and pseudo-second-order models. These kinetic models can explain the rate-controlling mechanism of the $\mathrm{Cr}(\mathrm{VI})$ adsorption process, such as chemical reaction, diffusion control, and mass transfer [32]. Therefore, the adsorption 
kinetic data were analyzed in terms of the pseudo-first-order and pseudo-second-order models (Table 2).

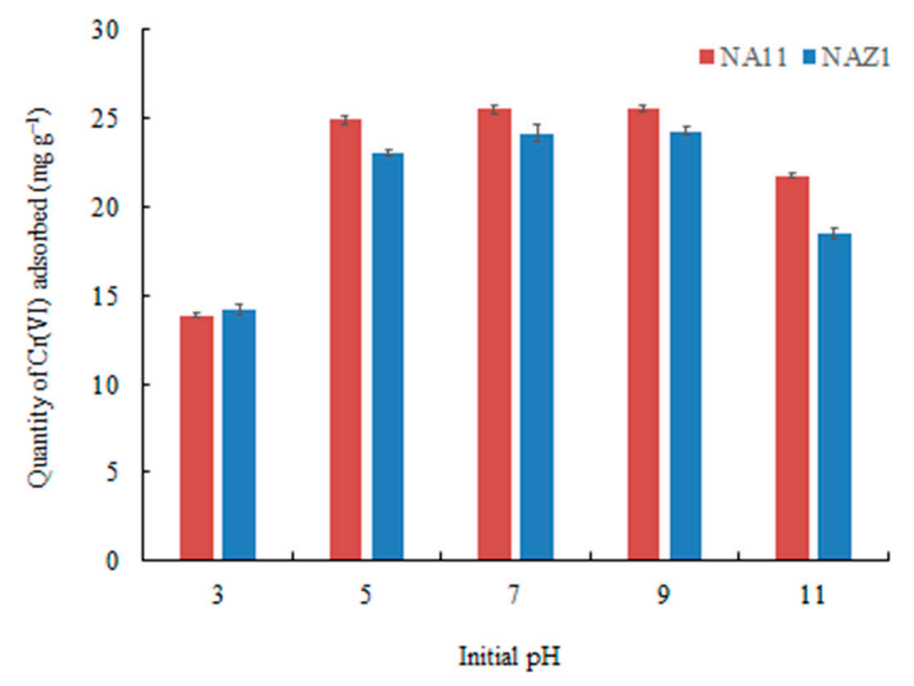

Figure 1. Effect of $\mathrm{pH}$ on the adsorption of $\mathrm{Cr}(\mathrm{VI})$ using NA11 and NAZ.

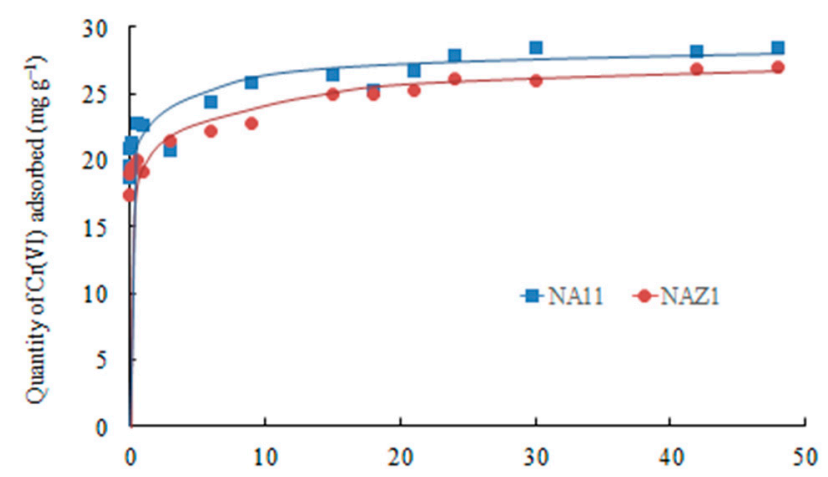

Contact time (h)

Figure 2. Effect of contact time on the adsorption of $\mathrm{Cr}(\mathrm{VI})$ using NA11 and NAZ1.

Table 2. Kinetic parameters for the adsorption of $\mathrm{Cr}(\mathrm{VI})$.

\begin{tabular}{|c|c|c|c|c|c|c|c|}
\hline \multirow[b]{2}{*}{ Adsorbents } & \multirow{2}{*}{$\begin{array}{c}q_{e} \\
\left(\mathrm{mg} \mathrm{g}^{-1}\right)\end{array}$} & \multicolumn{3}{|c|}{ Pseudo-First-Order Model } & \multicolumn{3}{|c|}{ Pseudo-Second-Order Model } \\
\hline & & $\begin{array}{c}k_{1} \\
\left(h^{-1}\right)\end{array}$ & $\begin{array}{c}q_{e} \\
\left(\mathrm{mg} \mathrm{g}^{-1}\right)\end{array}$ & $r$ & $\begin{array}{c}k_{2} \\
\left(\mathrm{~g} \mathrm{mg}^{-1} \mathrm{~h}^{-1}\right)\end{array}$ & $\begin{array}{c}q_{e} \\
\left(\mathrm{mg} \mathrm{g}^{-1}\right)\end{array}$ & $r$ \\
\hline NA11 & 28.5 & 0.22 & 8.0 & 0.870 & 0.04 & 28.4 & 0.999 \\
\hline NAZ1 & 27.0 & 0.09 & 8.8 & 0.972 & 0.04 & 26.8 & 0.999 \\
\hline
\end{tabular}

The pseudo-first-order and pseudo-second-order models were based on physical sorption and chemical sorption, respectively $[35,36]$. These equations are expressed as follows:

$$
\begin{gathered}
\ln \left(q_{e}-q_{t}\right)=\ln q_{e}-k_{1} t \\
\frac{t}{q_{t}}=\frac{t}{q_{e}}+\frac{1}{k_{2} \times q_{e}{ }^{2}},
\end{gathered}
$$

where $q_{e}$ and $q_{t}$ are the quantity of $\mathrm{Cr}(\mathrm{VI})$ adsorbed $\left(\mathrm{mg} \mathrm{g}^{-1}\right)$ at equilibrium and given time $t$, and $k_{1}$ and $k_{2}$ are the pseudo-first-order $\left(\mathrm{h}^{-1}\right)$ and pseudo-second-order $\left(\mathrm{g} \mathrm{mg}^{-1} \mathrm{~h}^{-1}\right)$ rate constants, respectively. The correlation coefficient $(r)$ in the pseudo-second-order model 
(0.999) was higher than that in the pseudo-first-order model (0.870-0.972). In addition, closer values of $q_{e}$ in the calculation $\left(26.8 \pm 0.01-28.4 \pm 0.02 \mathrm{mg} \mathrm{g}^{-1}\right)$ and experiment $\left(27.0 \pm 0.01-28.5 \pm 0.02 \mathrm{mg} \mathrm{g}^{-1}\right)$ indicate that the $\mathrm{Cr}(\mathrm{VI})$ adsorption data fit well with the pseudo-second-order model compared to the pseudo-first-order model. These results suggest that $\mathrm{Cr}(\mathrm{VI})$ oxyanions diffuse through the solution to the adsorbent's external surface and boundary layer [29].

Previous studies reported that metal hydroxide complexes can remove heavy metals from aqueous media by various mechanisms [32]. First, the adsorption onto the adsorbent external surface. Second, intercalation by ion exchange mechanism with anions in the interlayer adsorbent. Usually, a combination of the above-mentioned mechanisms easily occurs to remove heavy metals from aqueous media. We have already described the relationship between the amount of $\mathrm{Cr}(\mathrm{VI})$ adsorbed and the surface functional group in the above section, which indicates that the adsorption mechanism of $\mathrm{Cr}$ (VI) using NA11 and NAZ1 was related to the adsorbent surface. Additionally, the conditions of NA11 and NAZ1 surfaces before and after adsorption were observed (Figure 3). Warm color and cold color shows high concentration and low concentration, respectively. The value of chromium (Cr) intensity was from 2 to over 15 and from 2 to 15 for NA11 and NAZ1 before and after adsorption. Therefore, the chromium quantity clearly increased on the NA11 and NAZ1 surfaces after $\mathrm{Cr}(\mathrm{VI})$ adsorption.

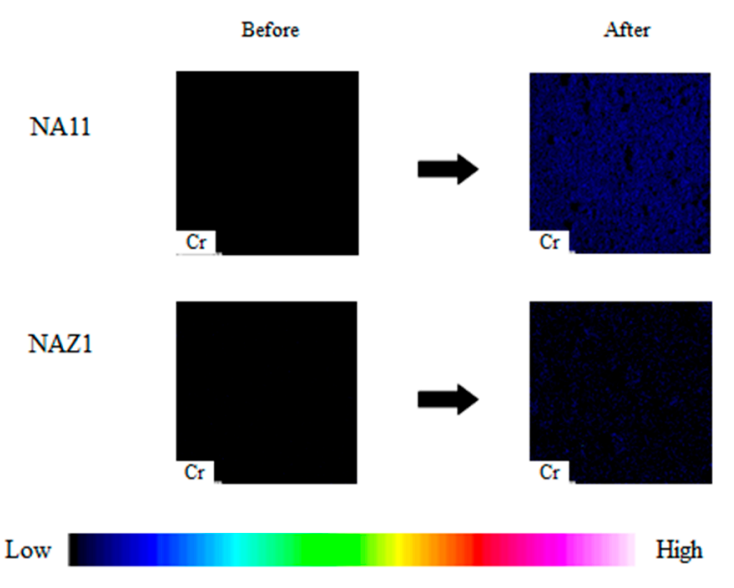

Figure 3. Elemental distribution of $\mathrm{Cr}(\mathrm{VI})$ onto NA11 and NAZ1 surface before and after adsorption.

The adsorption mechanism of $\mathrm{Cr}(\mathrm{VI})$ from aqueous media using NA11 and NAZ1 was also investigated in detail, anion exchange in the adsorption treatment (from Figure 2) was evaluated in this study. We measured the X-ray photoelectron spectra of the NA11 and NAZ1 surfaces before and after adsorption (Figure 4). $\mathrm{Cr}(2 \mathrm{p})$ peaks at $575-577$ eV were detected after adsorption, which was not detected before adsorption. On the other hand, the intensity of sulfur (165 eV for S(2p)) peak slightly or significantly decreased after adsorption of $\mathrm{Cr}(\mathrm{VI})$ using NA11 or NAZ1 in this study. In addition, Figure 5 shows the relationship between the quantity of $\mathrm{Cr}(\mathrm{VI})$ adsorbed and the quantity of sulfate ions released from the interlayer of NA11 and NAZ1. As shown in Figure 5, a positive linear relationship (correlation coefficient was 0.918 and 0.945 for NA11 and NAZ1, respectively) was observed under our experimental conditions. This result was proposed here that the sulfate ions in the interlayer of NA1 and NAZ1 were exchanged with $\mathrm{Cr}(\mathrm{VI})$.

Figure 6 exhibited the effect of temperature and the adsorption isotherms on $\mathrm{Cr}(\mathrm{VI})$ adsorption using NA11 and NAZ1. The quantity of $\mathrm{Cr}(\mathrm{VI})$ adsorbed using NA11 and NAZ1 was not different and slightly increased, respectively, at adsorption temperatures between 5 and $45^{\circ} \mathrm{C}$. Therefore, the adsorption temperature did not strongly affect the adsorption capability of $\mathrm{Cr}(\mathrm{VI})$ using NA11 and NAZ1 under our experimental conditions. 


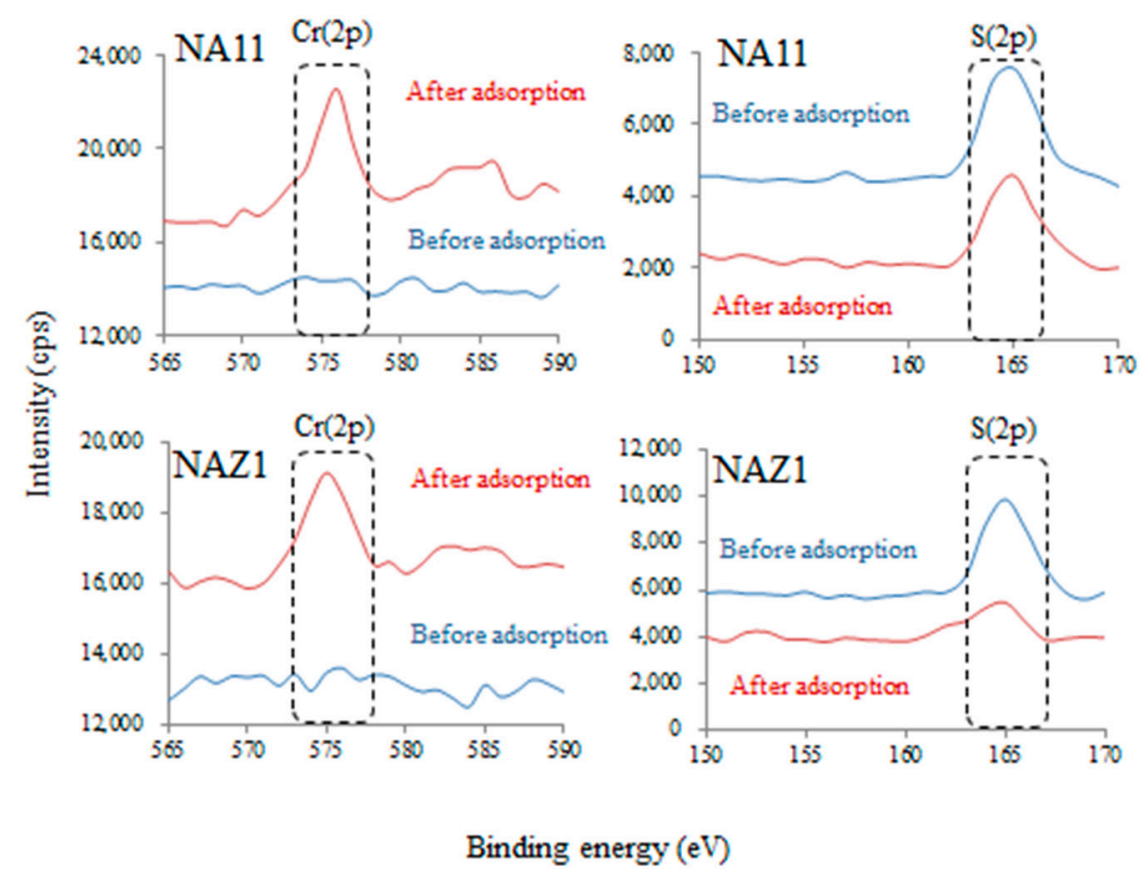

Figure 4. X-ray photoelectron spectrometry spectra of NA11 and NAZ1 before and after adsorption.

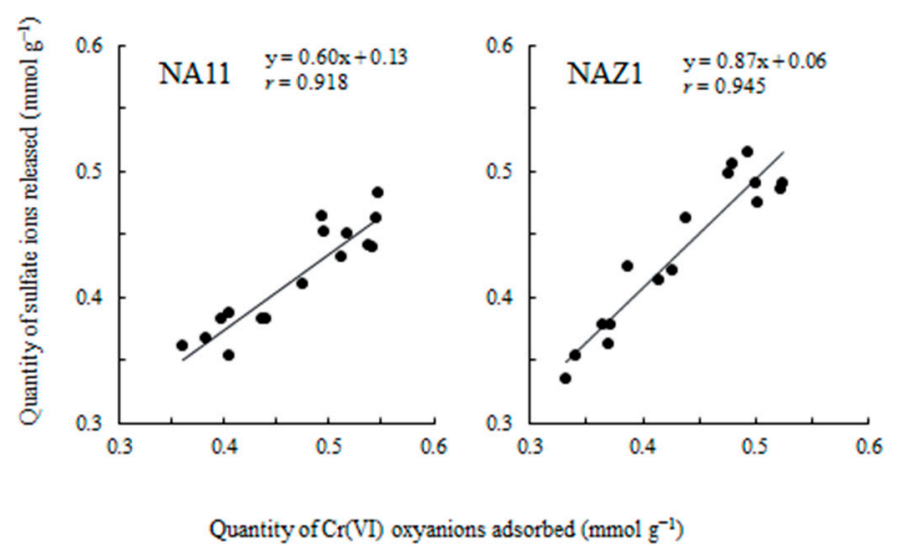

Figure 5. Relationship between quantity of $\mathrm{Cr}(\mathrm{VI})$ adsorbed and quantity of sulfate ions released.

Adsorption isotherm models are usually used to describe the interactions between adsorbates and adsorbents. Freundlich and Langmuir isotherms are empirical expressions of the adsorption process attributed to the special micro and macro structures of the adsorbents [37]. Freundlich's isotherm model allows for multilayered adsorption of adsorbates onto adsorbent surfaces [28]. Additionally, the Langmuir isotherm assumes an energetically homogeneous support surface with pervasively identical adsorption sites [38]. The Freundlich model is described by Equation (3) [39]:

$$
\log q=\frac{1}{n} \log C_{e}+\log k,
$$

The Langmuir model is described by Equation (4) [40]:

$$
1 / q=1 /\left(W_{s} a C_{e}\right)+1 / W_{s},
$$

where $q$ is the quantity of $\mathrm{Cr}(\mathrm{VI})$ adsorbed $\left(\mathrm{mg} \mathrm{g}^{-1}\right), W_{s}$ is the maximum quantity of adsorbed $\mathrm{Cr}(\mathrm{VI})\left(\mathrm{mg} \mathrm{g}^{-1}\right)$, and $C_{e}$ is the equilibrium concentration $\left(\mathrm{mg} \mathrm{L}^{-1}\right)$. The adsorption 
capacity and strength of adsorption are $k$ and $1 / n$, respectively. Additionally, $a$ is the Langmuir isotherm constant (binding energy) $\left(\mathrm{L} \mathrm{mg}^{-1}\right)$.

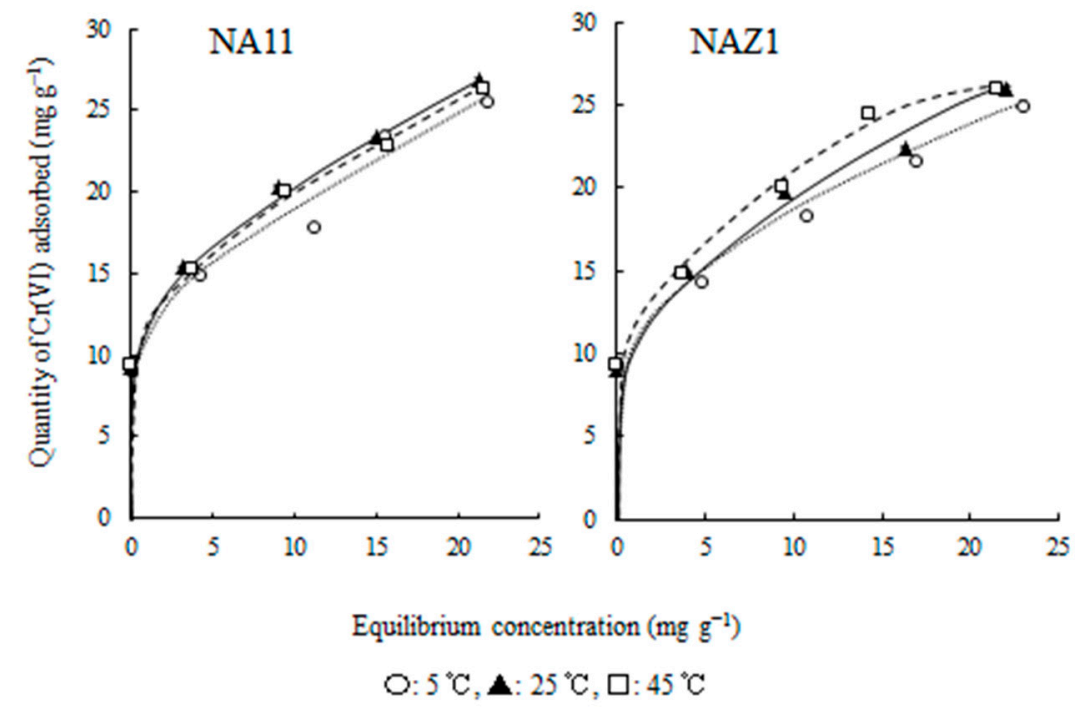

Figure 6. Adsorption isotherms of $\mathrm{Cr}(\mathrm{VI})$ using NA11 and NAZ1.

Table 3 showed the Freundlich and Langmuir constants for $\mathrm{Cr}(\mathrm{VI})$ adsorption using NA11 and NAZ1. As a result, the regression correlation coefficients (over 0.987) were presented for the Freundlich model, which were higher than those of the Langmuir model (over 0.917). These results indicate that the Freundlich isotherm model was more suitable for describing the adsorption equilibrium of $\mathrm{Cr}(\mathrm{VI})$ onto NA11 and NAZ1. The maximum adsorption capability $\left(W_{s}\right)$ of $\mathrm{Cr}(\mathrm{VI})$ increased with increasing adsorption temperature from 5 to $45^{\circ} \mathrm{C}$. These phenomena agree with the adsorption behaviors of $\mathrm{Cr}(\mathrm{VI})$ using NAZ1. Finally, when the value of $1 / n$ is $0.1-0.5, \mathrm{Cr}(\mathrm{VI})$ adsorption using NA11 and NAZ1 easily occurs. On the other hand, when the value of $1 / n$ is over 2 , adsorption is difficult [41]. In this study, the value of $1 / n$ is $0.31-0.34$, and then $\mathrm{Cr}(\mathrm{VI})$ adsorption from aqueous media using NA11 and NAZ1 were more favorable under our experimental condition.

Table 3. Freundlich and Langmuir constants for the adsorption of $\mathrm{Cr}(\mathrm{V})$.

\begin{tabular}{|c|c|c|c|c|c|c|c|}
\hline \multirow[b]{2}{*}{ Adsorbents } & \multirow[b]{2}{*}{ Temperature $\left({ }^{\circ} \mathrm{C}\right)$} & \multicolumn{3}{|c|}{ Freundlich Constants } & \multicolumn{3}{|c|}{ Langmuir Constants } \\
\hline & & $\log k$ & $1 / n$ & $r$ & $\begin{array}{c}W_{s} \\
\left(\mathrm{mg} \mathrm{g}^{-1}\right)\end{array}$ & $\begin{array}{c}a \\
\left(\mathrm{~L} \mathrm{mg}^{-1}\right)\end{array}$ & $r$ \\
\hline \multirow{4}{*}{ NA11 } & 5 & 0.96 & 0.33 & 0.987 & 27.4 & 0.28 & 0.917 \\
\hline & 25 & 0.99 & 0.34 & 0.993 & 27.9 & 0.38 & 0.979 \\
\hline & 45 & 0.98 & 0.33 & 0.998 & 28.5 & 0.30 & 0.984 \\
\hline & 5 & $-\overline{0.9 \overline{6}}$ & $\overline{0} . \overline{31}$ & $\overline{0} . \overline{9} 9 \overline{7}$ & $\overline{28.0}$ & $\overline{0} . \overline{22}$ & $\overline{0} \overline{979}$ \\
\hline \multirow[t]{2}{*}{ NAZ1 } & 25 & 0.96 & 0.33 & 0.998 & 28.4 & 0.27 & 0.986 \\
\hline & 45 & 0.97 & 0.34 & 0.998 & 30.0 & 0.26 & 0.989 \\
\hline
\end{tabular}

\subsection{Adsorption/Desorption Capability of Cr(VI) using NAZ1}

To evaluate the recovery of $\mathrm{Cr}(\mathrm{VI})$ adsorbed onto the NAZ1 surface, the adsorption/ desorption capability of $\mathrm{Cr}(\mathrm{VI})$ using NAZ1 was investigated in this study (Figure 7). As a result, the quantity of $\mathrm{Cr}(\mathrm{VI})$ desorbed from NAZ1 using a sodium hydroxide solution increased with increasing concentration of the desorption solution. The recovery percentages of $\mathrm{Cr}(\mathrm{VI})$ using 1,10 , and $100 \mathrm{mmol} \mathrm{L}^{-1}$ was $29.8 \%, 72.9 \%$, and $80.1 \%$, respectively, under our experimental conditions. The in-use studies in real samples are needed to elucidate the application of NAZ1 in further experiments. 


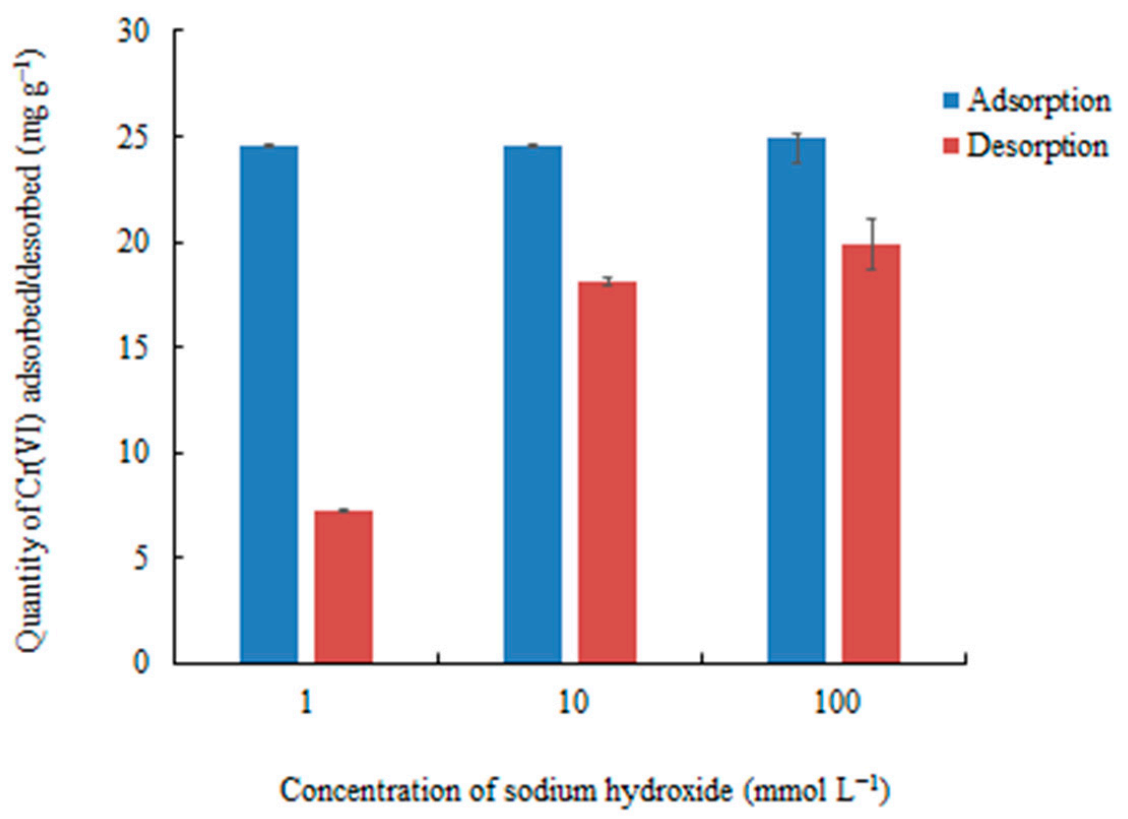

Figure 7. Adsorption/Desorption capability of Cr(VI) using NAZ1.

\section{Conclusions}

We prepared the NA and NAZ series adsorbents for $\mathrm{Cr}(\mathrm{VI})$ removal from aqueous media. Our results showed that NAZ1 was more suitable for $\mathrm{Cr}(\mathrm{VI})$ removal than NA11 under our experimental conditions. The optimal $\mathrm{pH}$ condition was approximately from 7.0 to 9.0 for removal of $\mathrm{Cr}(\mathrm{VI})$ from aqueous media. The kinetic experiments indicated that the adsorption process could reach equilibrium in approximately $20 \mathrm{~h}$, and the kinetic data were accurately described by pseudo-second-order model (Correlation coefficient was 0.999 for NA11 and NAZ1). From the results of elemental distribution, binding energy analysis, and relationship between quantity of $\mathrm{Cr}(\mathrm{VI})$ adsorbed and quantity of sulfate ion released from adsorbents, adsorption mechanism related to the adsorbent surface properties (surface hydroxyl groups), and ion exchanges in this study. The adsorption isotherm data agreed with well with the Freundlich model (Correlation coefficient was over 0.987) compared to Langmuir model (Correlation coefficient was over 0.917). Additionally, the recovery percentage of $\mathrm{Cr}(\mathrm{VI})$ from NAZ1 using $100 \mathrm{mmol} \mathrm{L}^{-1}$ was approximately $80 \%$. These findings are useful for the removal of $\mathrm{Cr}(\mathrm{VI})$ from aqueous media.

Author Contributions: Conceptualization, F.O. and N.K.; investigation, N.N., A.T., C.S., and T.N.; resources, M.T. and M.O.; writing-original draft preparation, F.O. and A.T.; writing-review and editing, F.O. and N.K.; project administration, N.K. All authors have read and agreed to the published version of the manuscript.

Funding: This research was supported in part by Kurita Water and Environment Foundation (20A003)

Institutional Review Board Statement: Not applicable.

Informed Consent Statement: Not applicable.

Data Availability Statement: MDPI is committed to supporting open scientific exchange and enabling our authors to achieve best practices in sharing and archiving research data. We encourage all authors of articles published in MDPI journals to share their research data. More details in section "MDPI Research Data Policies" at https:/ / www.mdpi.com/ethics.

Conflicts of Interest: The authors declare no conflict of interest. The funders had no role in the design of the study; in the collection, analyses, or interpretation of data; in the writing of the manuscript, or in the decision to publish the results. 


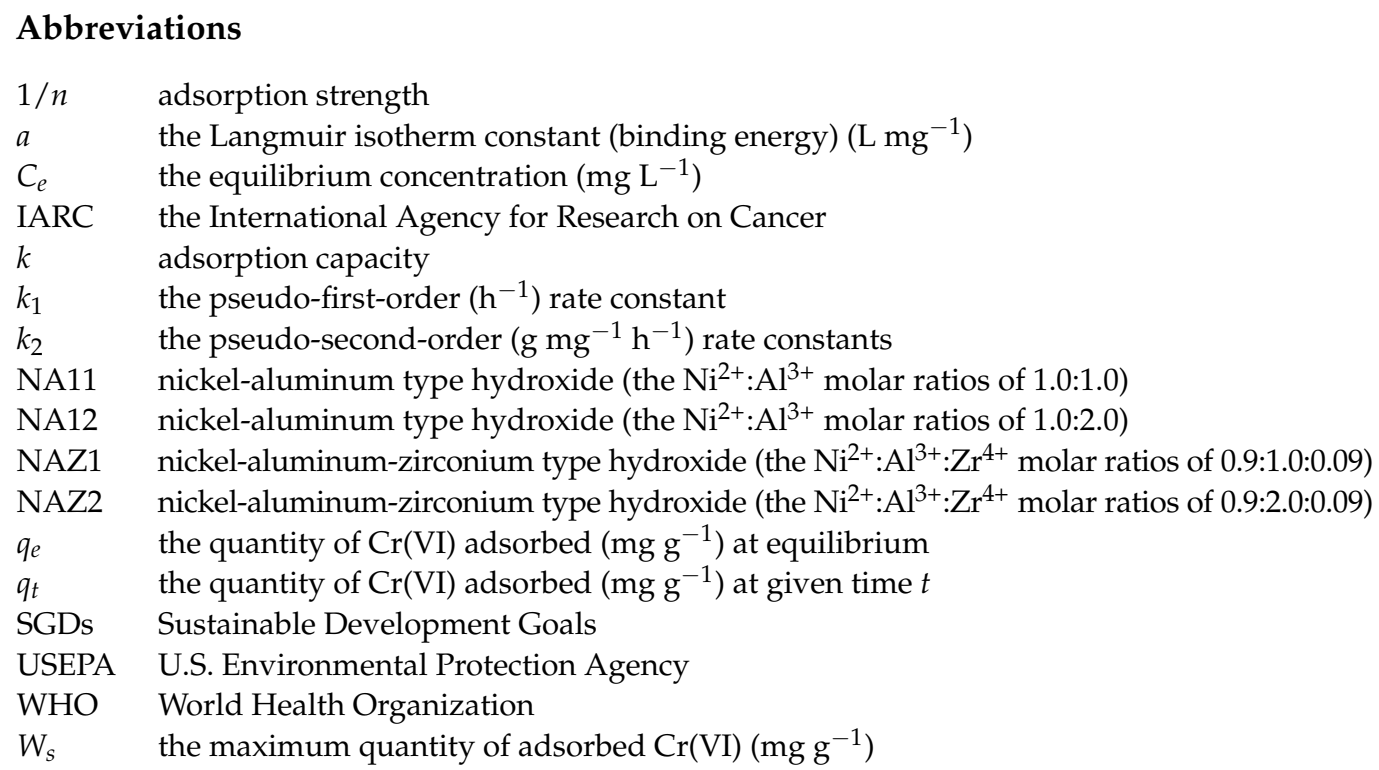

\section{References}

1. Liu, X.J.; Zeng, H.Y.; Xu, S.; Chen, C.R.; Zhang, Z.Q.; Du, Z.J. Metal oxides as dual-functional adsorbents/catalysts for Cu ${ }^{2+} / \mathrm{Cr}(\mathrm{VI})$ adsorption and, ethyl orange oxidation catalysis. J. Taiwan Inst. Chem. Eng. 2016, 60, 414-422. [CrossRef]

2. Li, Y.; Wang, J.; Li, Z.; Liu, Q.; Liu, J.; Liu, L.; Zhang, Z.; Yu, J. Ultrasound assisted synthesis of Ca-Al hydrotalcite for U(VI) and Cr(VI) adsorption. Chem. Eng. J. 2013, 218, 295-302. [CrossRef]

3. Dlugosz, A.; Rembacz, K.P.; Pruss, A.; Durlak, M.; Lembas-Bogaczyk, J. Influence of chromium on the natural antioxidant barrier. Polym. J. Environ. Stud. 2012, 21, 331-335.

4. Rao, M.V.; Jhala, D.D.; Patel, A.; Chettiar, S.S. Cytogenetic alteration induced by nickel and chromium in human blood cultures and its amelioration by curcumin. Int. J. Hum. Genet. 2008, 8, 301-306. [CrossRef]

5. Zhu, Y.; Jin, Y.; Chang, K.; Chen, Z.; Li, X.; Wu, X.; Jin, C.; Ye, F.; Shen, R.; Dong, W.; et al. Use of molybdenum disulfide nanosheets embellished nanoiron for effective capture of chromium(VI) ions from aqueous solution. J. Mol. Liq. 2018, 259, 376-383. [CrossRef]

6. Cao, E.; Duan, W.; Yi, L.; Wang, A.; Zheng, Y. Poly ( $m$-phenylenediamine) functionalized Calotropis gigantea fiber for coupled adsorption reduction for Cr(VI). J. Mol. Liq. 2017, 240, 225-232. [CrossRef]

7. Ogata, F.; Nagai, N.; Itami, R.; Nakamura, T.; Kawasaki, N. Potential of virgin and calcined wheat bran biomass for the removal of chromium(VI) ion from a synthetic aqueous solution. J. Environ. Chem. Eng. 2020, 8, 103710. [CrossRef]

8. Ogata, F.; Ueta, E.; Kawasaki, N. Characteristics of a novel adsorbent Fe-Mg-type hydrotalcite and its adsorption capability of As(III) and Cr(VI) from aqueous solution. J. Ind. Eng. Chem. 2018, 59, 56-63. [CrossRef]

9. Juang, R.S.; Shiau, R.C. Metal removal from aqueous solutions using chitosan-enhanced membrane filtration. J. Membr. Sci. 2000, 165, 159-167. [CrossRef]

10. Baral, S.S.; Das, S.N.; Rath, P.; Chaudhury, G.R. Chromium (VI) removal by calcined bauxite. Biochem. Eng. J. 2007, 34, 69-75. [CrossRef]

11. Harry, I.D.; Saha, B.; Cumming, I.W. Effect of electrochemical reduction and oxidation of a viscose rayon based activated carbon cloth for Cr(VI) sorption from aqueous solution. Ind. Eng. Chem. Res. 2008, 47, 6734-6741. [CrossRef]

12. Cappelletti, G.; Bianchi, C.L.; Ardizzone, S. Nano-titania assisted photoreduction of $\mathrm{Cr}(\mathrm{VI})$ : The role of the different TiO 2 polymorphs. Appl. Catal. B Environ. 2008, 78, 193-201. [CrossRef]

13. Ogata, F.; Kawasaki, N. Adsorption of As(III) from aqueous solutions by novel Fe-Mg type hydrotalcite. Chem. Pharm. Bull. 2015, 63, 1040-1046. [CrossRef]

14. Alvarez-Ayuso, E.; Nugteren, H.W. Purification of chromium(VI) finishing wastewaters using calcined and uncalcined Mg-Al$\mathrm{CO}_{3}$-hydrotalcite. Water Res. 2005, 39, 2535-2542. [CrossRef] [PubMed]

15. Lazaridis, N.K.; Asouhidou, D.D. Kinetics of sorptive removal of chromium(VI) drom aqueous solutions by calcined $\mathrm{Mg}^{-\mathrm{Al}-\mathrm{CO}} 3$ hydrotalcite. Water Res. 2003, 37, 2875-2882. [CrossRef]

16. Rodrigues, E.; Almeida, O.; Brasil, H.; Moraes, D.; dos Reis, M.A.L. Adsorption of chromium(VI) on hydrotalcit-hydroxyapatite material doped with carbon nanotubes: Equilibrium, kinetic and thermodynamic study. Appl. Clay Sci. 2019, 172, 57-64. [CrossRef]

17. Deng, L.; Shi, Z.; Li, B.; Yang, L.; Luo, L.; Yang, X. Adsorption of Cr(VI) and phosphate on Mg-Al hydrotalcite supported kaoline clay prepared by ultrasound-assisted coprecipitation method using batch and fixed-bed systems. Ind. Eng. Chem. Res. 2014, 53, 7746-7757. [CrossRef]

18. Chen, C.R.; Zeng, H.Y.; Xu, S.; Liu, X.J.; Duan, H.Z.; Han, J. Preparation of mesoporous material from hydrotalcite/carbon composite precursor for chromium(VI) removal. J. Taiwan Inst. Chem. Eng. 2017, 70, 302-310. [CrossRef] 
19. Aregay, G.G.; Jawad, A.; Du, Y.; Shahzad, A.; Chen, Z. Efficient and selective removal of chromium(VI) by sulfide assembled hydrotalcite compounds through concurrent reduction and adsorption processes. J. Mol. Liq. 2019, 294, 111532. [CrossRef]

20. Xiao, L.; Ma, W.; Han, M.; Cheng, Z. The influence of ferric iron in calcined nano-Mg/ $\mathrm{Al}$ hydrotalcite on adsorption of Cr(VI) from aqueous solution. J. Hazard. Mater. 2011, 186, 690-698. [CrossRef]

21. Ogata, F.; Nakamura, T.; Toda, M.; Otani, M.; Kawasaki, N. Evaluation of nickel-aluminum complex hydroxide for adsorption of chromium(VI) ion. Chem. Pharm. Bull. 2020, 68, 70-76. [CrossRef]

22. Ogata, F.; Nagai, N.; Toda, M.; Otani, M.; Saenjum, C.; Nakamura, T.; Kawasaki, N. Removal of arsenic(III) ion from aqueous media using complex nickel-aluminum and nickel-aluminum-zirconium hydroxides. Water 2020, 12, 1697. [CrossRef]

23. Ogata, F.; Iijima, S.; Toda, M.; Otani, M.; Nakamura, T.; Kawasaki, N. Characterization and phosphate adsorption capability of novel nickel-aluminum-zirconium complex hydroxide. Chem. Pharm. Bull. 2020, 68, 292-297. [CrossRef]

24. Long, F.; Gong, J.L.; Zeng, G.M.; Chen, L.; Wang, X.Y.; Deng, J.H.; Niu, Q.Y.; Zhang, H.Y.; Zhang, X.R. Removal of phosphate from aqueous solution by magnetic Fe-Zr binary oxide. Chem. Eng. J. 2011, 171, 448-455. [CrossRef]

25. Faria, P.C.C.; Orfao, J.J.M.; Pereira, M.F.R. Adsorption of anionic and cationic dyes on activated carbons with different surface chemistries. Water Res. 2004, 38, 2043-2052. [CrossRef] [PubMed]

26. Chitrakar, R.; Tezuka, S.; Sonoda, A.; Sakane, K.; Ooi, K.; Hirotsu, T. Synthesis and phosphate uptake behavior of $\mathrm{Zr}^{4+}$ incorporated MgAl-layered double hydroxides. J. Colloid Interf. Sci. 2007, 313, 53-63. [CrossRef]

27. Miyauchi, H.; Yamamoto, T.; Chitrakar, R.; Makita, Y.; Wang, Z.; Kawai, J.; Hirotsu, T. Phosphate adsorption site on zirconium ion modified MgAl-layered double hydroxides. Top. Catal. 2009, 52, 714-723. [CrossRef]

28. Wang, W.; Zhou, J.; Achari, G.; Yu, J.; Cai, W. Cr(VI) removal from aqueous solutions by hydrothermal synthetic layered double hydroxides: Adsorption performance, coexisting anions and regeneration studies. Colloids Surf. A Physicochem. Eng. Asp. 2014, 457, 33-40. [CrossRef]

29. Lu, Y.; Jiang, B.; Fang, L.; Ling, F.; Gao, J.; Wu, F.; Zhang, X. High performance NiFe layered double hydroxide for methyl orange dye and $\mathrm{Cr}(\mathrm{VI})$ adsorption. Chemosphere 2016, 152, 415-422. [CrossRef]

30. Yue, X.; Liu, W.; Chen, Z.; Lin, Z. Simultaneous removal of $\mathrm{Cu}(\mathrm{II})$ and $\mathrm{Cr}(\mathrm{VI})$ by $\mathrm{Mg}-\mathrm{Al}-\mathrm{Cl}$ layered double hydroxide and mechanism insight. J. Environ. Sci. 2017, 53, 16-26. [CrossRef]

31. Lazaridis, N.K.; Pandi, T.A.; Matis, K.A. Chromium(VI) removal from aqueous solutions by Mg-Al-CO $\mathrm{C}_{3}$ hydrotalcite: Sorptiondesorption kinetic and equilibrium studies. Ind. Eng. Chem. Res. 2004, 43, 2209-2215. [CrossRef]

32. Khitous, M.; Salem, Z.; Halliche, D. Effect of interlayer anions on chromium removal using Mg-Al layered double hydroxides: Kinetic, equilibrium and thermodynamic studies. Chinese J. Chem. Eng. 2016, 24, 433-445. [CrossRef]

33. Li, Y.; Gao, B.; Wu, T.; Sun, D.; Li, X.; Wang, B.; Lu, F. Hexavalent chromium removal from aqueous solution by adsorption on aluminum magnesium mixed hydroxide. Water Res. 2009, 43, 3067-3075. [CrossRef] [PubMed]

34. Yan, L.G.; Yang, K.; Shan, R.R.; Yu, H.Q.; Du, B. Calcined ZnAl- and $\mathrm{Fe}_{3} \mathrm{O}_{4} / \mathrm{ZnAl}$-layered double hydroxides for efficient removal of $\mathrm{Cr}(\mathrm{VI})$ from aqueous solution. RSC Adv. 2015, 5, 96495. [CrossRef]

35. Enshirah, D.; Silva, N.D.; Sayari, A. Adsorption of copper on amine functionalized SBA-15 prepared by co-condensation: Kinetic properties. Chem. Eng. J. 2011, 166, 454-459.

36. Demirbas, E.; Dizge, N.; Sulak, M.T.; Kobya, M. Adsorption kinetics and equilibrium of copper from aqueous solutions using hazelnut shell activated carbon. Chem. Eng. J. 2009, 148, 480-487. [CrossRef]

37. Atkin, P.W. Physical Chemistry, 6th ed.; Oxford University Press: Oxford, UK, 1998.

38. Vimonses, V.; Lei, S.; Bo, J.; Chow, C.W.K.; Saint, C. Kinetic study and equilibrium isotherm analysis of congo red adsorption by clay materials. Chem. Eng. J. 2009, 148, 354-364. [CrossRef]

39. Freundlich, H.M.T. Over the adsorption in solution. J. Phys. Chem. 1906, 57, 385-471.

40. Langmuir, I. The constitution and fundamental properties of solids and liquids. J. Am. Chem. Soc. 1916, 38, 2221-2295. [CrossRef]

41. Abe, I.; Hayashi, K.; Kitagawa, M. Studies on the adsorption of surfactants on activated carbons. I. Adsorption of nonionic surfactants. Yukagaku 1976, 25, 145-150. 